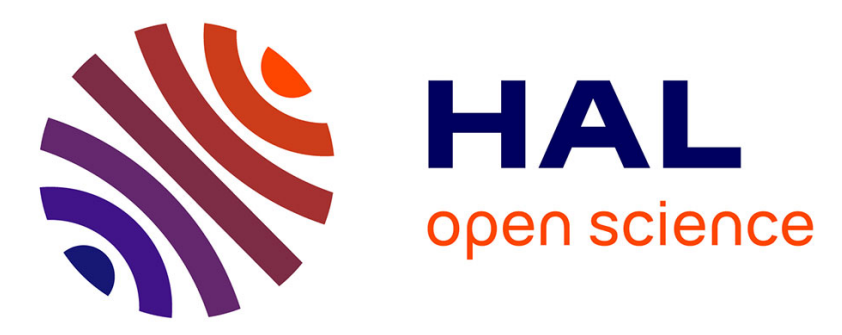

\title{
Effect of I199V polymorphism on prkag3 gene on carcass and meat quality traits in slovenian commercial pigs
}

\author{
Martin Skrlep, Veronique Sante-Lhoutellier
}

\section{To cite this version:}

Martin Skrlep, Veronique Sante-Lhoutellier. Effect of I199V polymorphism on prkag3 gene on carcass and meat quality traits in slovenian commercial pigs. Journal of Muscle Foods, 2009, 20 (3), pp.367376. 10.1111/j.1745-4573.2009.00158.x . hal-02669232

\section{HAL Id: hal-02669232 \\ https://hal.inrae.fr/hal-02669232}

Submitted on 31 May 2020

HAL is a multi-disciplinary open access archive for the deposit and dissemination of scientific research documents, whether they are published or not. The documents may come from teaching and research institutions in France or abroad, or from public or private research centers.
L'archive ouverte pluridisciplinaire HAL, est destinée au dépôt et à la diffusion de documents scientifiques de niveau recherche, publiés ou non, émanant des établissements d'enseignement et de recherche français ou étrangers, des laboratoires publics ou privés. 


\title{
EFFECT OF I199V POLYMORPHISM ON PRKAG3 GENE ON CARCASS AND MEAT QUALITY TRAITS IN SLOVENIAN COMMERCIAL PIGS
}

\author{
M. ŠKRLEP ${ }^{1}$, T. KAVAR ${ }^{1}$, V. SANTÉ-LHOUTELLIER ${ }^{2}$ and \\ M. ČANDEK-POTOKAR ${ }^{1,3}$ \\ ${ }^{1}$ Agricultural Institute of Slovenia \\ Hacquetova 17, 1000 Ljubljana, Slovenia \\ ${ }^{2}$ INRA, UR370 QuaPA \\ F-63122 Saint Genès Champanelle, France
}

Accepted for Publication March 19, 2008

\begin{abstract}
The effect of I199V polymorphism at the PRKAG3 gene on carcass and meat quality of commercial pigs was studied independently from PRKAG3 200Q or RYR1 " $n$ " allele, known to decrease meat quality, i.e., animals were genotyped for RYR1 R615C, PRKAG3 I199V and R200Q substitutions, and only pigs without $200 Q$ and " $n$ " were retained for the analysis of carcass and meat quality traits $(\mathrm{n}=274)$. Genotype frequencies were 12.0, 57.7 and $30.3 \%$ for I/I, I/V and V/V, respectively. The I199V polymorphism affected significantly fat thickness and drip loss and tended to affect ultimate $p H$. Interestingly, I/ $\mathrm{V}$ were the fattest and significantly different from $\mathrm{V} / \mathrm{V}$, with $\mathrm{I} / \mathrm{I}$ pigs being intermediate. The ultimate $\mathrm{pH}$ of I/I was higher than the one of I/V or $V / V$ pigs. Regarding drip loss, significant difference was detected between I/I and $V / V$ pigs. The heterozygous I/V pigs were intermediate with differences to I/I or V/V tending toward significance.
\end{abstract}

\section{PRACTICAL APPLICATIONS}

Our results provide new evidence about the significant effect of second polymorphism on the PRKAG3 gene (I199V) on carcass and meat quality. Because of low frequencies of I/I genotype in the majority of modern pig breeds, the available literature data for genotype I/I are scarce. Our results confirm a beneficial impact of 199I allele for pork quality, but indicate possible

\footnotetext{
${ }^{3}$ Corresponding author. TEL: +386 1 2805124; FAX: +386 1 2805255; EMAIL: meta.candekpotokar@kis.si
} 
adverse impact for carcass leanness. It would be worthwhile rechecking the interesting position of heterozygous I/V pigs, which turned out to be the fattest. We expect the results to be useful for breeders in search of the compromise between carcass and meat quality.

\section{INTRODUCTION}

Many factors affect pork quality; however, as regards the genotype, mainly RYR1 R615C (hal gene) and PRKAG3 R200Q (RN gene) substitutions have been thoroughly investigated. By favoring calcium release in muscle cells, the recessive RYR1 " $\mathrm{n}$ " allele influences the rate of $\mathrm{pH}$ fall (Gueblez et al. 1995; De Smet et al. 1996; Larzul et al. 1997; Monin et al. 1999; Fisher et al. 2000), while the dominant allele $\mathrm{RN}^{-}$(200Q) causes high glycogen levels, and consequently, lower ultimate $\mathrm{pH}$ (Le Roy et al. 1990; Sellier and Monin 1994; Le Roy et al. 2000); both genes consequently exerting impact on meat water-holding capacity. Both alleles, a dominant 200Q $\left(\mathrm{RN}^{-}\right)$and RYR1 " $n$ " allele, exert beneficial impact on leanness (Pommier et al. 1992; Leach et al. 1996; Hamilton et al. 2000; Le Roy et al. 2000). Presently, a lot of research is dealing with the PRKAG3 gene, which encodes a muscle specific isoform of the regulatory $\gamma$-subunit of the adenosine monophosphate-activated protein kinase, an enzyme that has a key role in regulating energy metabolism. Five nonsynonymous substitutions (T30N, G52S, L53P, I199V and R200Q) have been detected in the PRKAG3 gene (Milan et al. 2000; Ciobanu et al. 2001). In addition to R200Q substitution, I199V showed the most significant effect on meat quality (i.e. muscle $\mathrm{pH}$ and color) with the allele 199I being considered as more favorable (Ciobanu et al. 2001; Lindahl et al. 2004a,b). There is a need for more information regarding the effect of PRKAG3 codon 199 polymorphism on carcass and meat quality, in particular being separated from the effect of 200Q allele. Therefore, the aim of the present study was to add to the body of knowledge that exists on the effects of polymorphisms on the PRKAG3 gene, providing more evidence on how I199V polymorphism affects carcass and meat quality traits independently from allele 200Q, as well as the RYR1 recessive " $n$ " allele.

\section{MATERIALS AND METHODS}

\section{Animals and Harvesting}

The present analysis is based on phenotypic data collection from field trials conducted over a period of 2 years and collected from 407 pigs coming 
from two herds, and slaughtered in two abattoirs in 11 batches. All animals were genotyped for RYR1 C1843T (R615C) according to Brenig and Brem (1992), and for PRKAG3 I199V and PRKAG3 R200Q substitutions (Milan et al. 2000). Pigs having 200Q allele, i.e., $\mathrm{RN}^{-}$phenotype or carrying RYR1 mutation (N/n) were excluded from the analysis, compliant with the aim of the study. Thus, for carcass and meat quality evaluation only, a subsample of 274 pigs were retained. Pigs were approximately 6-month-old commercial crosses of both genders and came from two herds; herd A, which was producing commercial pigs sired by Pietrain $(\mathrm{Pi})$ or Pietrain $\times$ Hampshire $(\mathrm{Pi} \times \mathrm{H})$ boars, and herd $\mathrm{B}$, which produces commercial pigs sired by Duroc (Du) or Duroc $\times$ Hampshire $(\mathrm{Du} \times \mathrm{H})$ boars (with Landrace $\times$ Large white female line). Animals were slaughtered according to the routine abattoir procedure, i.e., $\mathrm{CO}_{2}$ stunning, vertical exsanguination, vapor scalding, dehairing and evisceration, followed by veterinary inspection and carcass classification. At the end of the slaughter line, small pieces of ear laps were taken for genetic analysis.

\section{Carcass and Meat Quality Measurements}

Carcass properties were measured on the first day on the slaughter line using a HGP4 Hennessy grading probe (Hennessy Grading Systems Ltd., Auckland, New Zealand) with puncture between the second and third last rib, $7 \mathrm{~cm}$ laterally from the carcass split line. One day after the slaughter, further carcass and meat quality measurements were performed. The hind leg was cut off the carcass between the 6th and the 7th lumbar vertebrae, and the shank was removed. The weight of the leg (ham) was recorded before and after the removal of the skin and subcutaneous fat and ham leanness (\%) assessed as the ratio between muscle with bones and whole ham weight. A cross section of the carcass was made at the level of the last rib and a digital image of the cross section was taken using a digital photo camera (Canon PowerShot G3, Canon Inc., Tokyo, Japan). Longissimus dorsi muscle (LD) area, corresponding fat area were determined on images with aid of LUCIA.NET 1.16.5 software (Laboratory Imaging s.r.o, Prague, Czech Republic). The measurements of color and $\mathrm{pH}$ were taken on the freshly cut surface of LD. The color of the LD was assessed using a six-point Japanese color scale (Nakai et al. 1975). Color parameter measurements (CIE $L^{*}, a^{*}$ and $b^{*}$ ) were taken in triplicate using a Minolta Chroma Meter CR-300 (Minolta Co. Ltd, Osaka, Japan) with an 11-mm diameter aperture, $\mathrm{D}_{65}$ illuminant, calibrated against a white tile. Muscle $\mathrm{pH}$ was determined in two replicates in the central area of the LD using a MP120 Mettler Toledo pH meter (Mettler-Toledo, GmbH, 8603 Schwarzenbach, Switzerland) fitted with a combined glass electrode (InLab427) and previously calibrated at $\mathrm{pH} 4.0$ and 7.0. Also, a 2.5-cm thick slice of LD was 
removed from the loin at the level of last rib for drip loss determination according to the EZ drip loss method published by Christensen (2003). Drip loss was determined after 24 and $48 \mathrm{~h}$ storage at $4 \mathrm{C}$ and expressed as a percentage of the initial weight. The intramuscular fat content of LD was estimated on minced samples with NIRS (NIR System model 6500 Spectrometer, Silver Spring, MD) as described in Prevolnik et al. (2005).

\section{Statistical Analysis}

Analysis of variance was performed using a statistical package SAS (SAS Inst., Inc., Cary, NC) and the procedure MIXED. The model included fixed effects of herd, PRKAG3 I199V genotypes (I/I, I/V, V/V), the gender, the breed cross nested within herd and the two-way interaction (herd $\times$ PRKAG3 I199V). The slaughter batch within the herd was included as a random effect. Significant differences between least square means were evaluated using the option PDIFF. No significant effect of the interaction of herd and PRKAG3 I199V genotypes was found.

\section{RESULTS AND DISCUSSION}

\section{Genotype Frequencies}

The occurrence of RYR1 and PRKAG3 genotypes in the studied sample of Slovenian commercial pigs is presented in Table 1. In total, our sample

TABLE 1.

FREQUENCY (N) OF GENOTYPES AT TWO GENES (PRKAG3 AND RYR1) IN THE STUDIED SAMPLE OF SLOVENIAN COMMERCIAL PIGS

\begin{tabular}{lllllll}
\hline $\begin{array}{l}\text { PRKAG3 codon } \\
200\end{array}$ & RYR1 & Herd* & \multicolumn{2}{l}{ PRKAG3 codon 199 } & & $\begin{array}{l}\text { Number } \\
\text { of pigs }\end{array}$ \\
\cline { 5 - 6 } & & & I/I & I/V & V/V & \\
\hline rn+/rn+ (R/R) & N/N & A & 16 & 62 & 40 & 118 \\
& N/N & B & 17 & 96 & 43 & 156 \\
& Total† & A+B & 33 & 158 & 83 & 274 \\
& N/n & A & 9 & 38 & 44 & 91 \\
RN-/rn+ (Q/R) & N/N & A & 0 & 6 & 21 & 27 \\
& N/n & A & 0 & 6 & 11 & 17 \\
& Total & & 42 & 208 & 159 & 409 \\
\hline
\end{tabular}

* Herd A pigs were crosses sired by Pietrain and Pietrain $\times$ Hampshire boars while herd B pigs were crosses sired by Duroc and Duroc $\times$ Hampshire boars.

$\dagger$ The subsample of pigs retained for the analysis of I199V polymorphism effect on carcass and meat quality traits. 
comprised 409 pigs, out of which $26.4 \%$ were carriers of RYR1 " $n$ " allele $(\mathrm{N} / \mathrm{n})$, and $10.8 \%(n=44)$ were $\mathrm{RN}^{-}$pigs $(\mathrm{Q} / \mathrm{R}$ at the PRKAG3 200 codon), while the observed frequencies of PRKAG3 codon 199 genotypes were $9.8 \%$ $(\mathrm{I} / \mathrm{I}), 51.1 \%(\mathrm{I} / \mathrm{V})$ and $39.1 \%(\mathrm{~V} / \mathrm{V})$. After the exclusion of carriers of mutant alleles on RYR1 (n) and PRKAG3 (200Q), our subsample comprised 12.0\% $(\mathrm{I} / \mathrm{I}), 57.7 \%(\mathrm{I} / \mathrm{V})$ and $30.3 \%(\mathrm{~V} / \mathrm{V})$. The frequencies of genotypes differed according to herd, given that herd $\mathrm{A}$ was using $\mathrm{Pi}$ and $\mathrm{Pi} \times \mathrm{H}$, and herd $\mathrm{B}$ was using $\mathrm{Du}$ and $\mathrm{Du} \times \mathrm{H}$ sires. Thus, herd A had pigs with both mutant alleles (n, 200Q), whereas herd B only had pigs free of the mentioned mutations. Our results show low incidence of I/I genotype, which corroborates the available literature reports for different modern breeds or crosses (Ciobanu et al. 2001; Josell et al. 2003; Huang et al. 2004; Lindahl et al. 2004a,b; Stalder et al. 2005; Otto et al. 2007). The only breed for which the reported frequency of I/I genotype is considerably higher (74\%) is the Berkshire breed (Ciobanu et al. 2001). In agreement with the literature, I/I genotype was always associated with 200R allele. Milan et al. (2000) showed that because of the absence of recombination between two neighboring codons (199 and 200), only three haplotypes are present in the domestic pig; 199I-200R and 199V-200R are considered as ancestral haplotypes, and were identified in most of the breeds, including wild boar, while 199V-200Q is considered as most recent since it was identified only in Hampshire breed. According to Ciobanu et al. (2001), the $\mathrm{RN}^{-}$phenotype appear to be a combined effect of haplotype 199V-200Q rather than a mere result of R200Q substitution, which was the reason for our decision to investigate the effect of codon 199 polymorphism without interference of $200 \mathrm{Q}$ allele. For the same reason, we also excluded carriers of RYR1 gene " $n$ " allele in our analysis of carcass and meat quality.

\section{Carcass Traits}

In the present study, the I199V polymorphism on the PRKAG3 gene showed a significant effect on subcutaneous fat thickness (Table 2). It affected backfat thickness measured with HGP probe at the level of $2 / 3$ last rib $(P=0.05)$ and fat area over LD muscle measured at the cross section at the level of last rib $(P=0.05)$. On the contrary, no significant effect of $1199 \mathrm{~V}$ polymorphism was observed on ham leanness. Interestingly, heterozygous (I/V) pigs were the fattest (the thickest backfat, largest fat area), and V/V pigs the leanest, while I/I pigs showed an intermediate position. In our opinion, these results indicate that 199I allele might be less favorable for leanness. There is not much data in the literature about the effect of I199V PRKAG3 polymorphisms on carcass composition. In particular, the information for I/I genotype is very limited. The available studies of Enfält et al. (2006), Lindahl et al. (2004a,b) and Josell et al. (2003) pooled the results of I/I and I/V 
TABLE 2.

LEAST SQUARE MEANS (SE) OF I199V GENOTYPES FOR CARCASS TRAITS

\begin{tabular}{lrrrr}
\hline & \multicolumn{2}{c}{ PRKAG3 codon 199} & \multirow{2}{*}{$P$} \\
\cline { 2 - 4 } & \multicolumn{1}{c}{$\mathrm{I} / \mathrm{I}$} & \multicolumn{1}{c}{$\mathrm{I} / \mathrm{V}$} & \multicolumn{1}{c}{ V/V } & \\
\hline Number of pigs & 33 & 158 & 83 & \\
Carcass weight $(\mathrm{kg})$ & $93.6(2.3)$ & $94.1(2.0)$ & $93.5(2.0)$ & 0.87 \\
HGP fat $(\mathrm{mm}) \dagger$ & $14.6^{\mathrm{a}, \mathrm{b}}(0.7)$ & $15.2^{\mathrm{a}}(0.5)$ & $14.2^{\mathrm{b}}(0.6)$ & 0.05 \\
HGP muscle $(\mathrm{mm}) \dagger$ & $59.6(1.6)$ & $61.9(1.3)$ & $61.1(1.3)$ & 0.21 \\
HGP meat $(\%) \dagger$ & $60.0(0.7)$ & $59.7(0.5)$ & $60.3(0.5)$ & 0.45 \\
LD area $\left(\mathrm{cm}^{2}\right) \ddagger$ & $50.0(1.4)$ & $51.9(1.2)$ & $50.9(1.2)$ & 0.13 \\
Fat area $\left(\mathrm{cm}^{2}\right) \ddagger$ & $14.6^{\mathrm{a}, \mathrm{b}}(0.9)$ & $15.2^{\mathrm{a}}(0.7)$ & $14.0^{\mathrm{b}}(0.7)$ & 0.05 \\
Ham (muscle + bones) $(\mathrm{kg})$ & $9.7(0.3)$ & $10.0(0.3)$ & $9.8(0.3)$ & 0.33 \\
Ham (kg) & $11.8(0.4)$ & $12.1(0.3)$ & $11.9(0.3)$ & 0.21 \\
Ham leanness $(\%)$ & $83.1(1.0)$ & $82.4(0.8)$ & $82.3(0.8)$ & 0.63 \\
\hline
\end{tabular}

a,b Least squares means within a row and followed by a different letter are significantly $(P<0.05)$ different.

$\dagger \quad$ Measured with Hennessy grading probe between 2nd and 3rd last rib.

\$ Measured at the cross section of Longissimus dorsi muscle at the level of last rib.

genotype into one genotype group due to, as they explained, very low frequencies of I/I genotype and the absence of important differences between I/I and I/V pigs for most of the measured traits. Despite that, Enfält et al. (2006), in their conclusion, also indicated that the presence of allele 199I decreased the lean meat content compared to two other alleles (199V-200Q and 199V-200R).

\section{Meat Quality}

The effect of PRKAG3 codon 199 polymorphisms on some meat quality traits proved to be important (Table 3). A significant effect was observed in the water-holding capacity, while it only tended to be significant in case of ultimate $\mathrm{pH}(\mathrm{pHu})$. On the other hand, no significant effect was observed on the LD color. In agreement with other studies (Josell et al. 2003; Lindahl et al. 2004a; Otto et al. 2007), no significant effect was observed for intramuscular fat content, LD muscle ultimate $\mathrm{pH}$ was significantly higher in $\mathrm{I} / \mathrm{I}$ homozygous pigs, compared to V/V genotype, with I/V pigs being closer to V/V pigs, which corroborates the results of Ciobanu et al. (2001) and Otto et al. (2007). Regarding the color, in the present study, PRKAG3 I199V genotypes were not significantly different in color measurements (Minolta $L^{*}, a^{*}$ and $b^{*}$ color note), although a slight tendency could be detected in the Minolta $L$ value and color note (I/I versus V/V). On the contrary, Ciobanu et al. (2001) reported 
TABLE 3.

LEAST SQUARES MEANS (SE) OF I199V GENOTYPES FOR MEAT QUALITY TRAITS

\begin{tabular}{lcccc}
\hline & \multicolumn{2}{l}{ PRKAG3 codon 199 } & \multirow{2}{*}{$P$} \\
\cline { 2 - 4 } & \multicolumn{1}{l}{$\mathrm{I} / \mathrm{I}$} & $\mathrm{I} / \mathrm{V}$ & $\mathrm{V} / \mathrm{V}$ & \\
\hline Number of pigs & 33 & 158 & 83 & \\
$\mathrm{Imf}(\%) \dagger$ & $1.45(0.08)$ & $1.39(0.06)$ & $1.42(0.06)$ & 0.62 \\
$\mathrm{pHu}$ & $5.58^{\mathrm{a}}(0.03)$ & $5.52^{\mathrm{b}}(0.03)$ & $5.51^{\mathrm{b}}(0.03)$ & 0.07 \\
LD color $(1-6) \dagger$ & $3.6(0.1)$ & $3.5(0.1)$ & $3.4(0.1)$ & 0.28 \\
Minolta $L^{*}$ & $49.7(0.6)$ & $50.5(0.5)$ & $51.0(0.5)$ & 0.15 \\
Minolta $a^{*}$ & $6.5(0.3)$ & $6.9(0.3)$ & $6.9(0.3)$ & 0.23 \\
Minolta $b^{*}$ & $2.9(0.2)$ & $3.0(0.2)$ & $3.0(0.2)$ & 0.93 \\
$a^{*} / b^{*}$ & $2.5(0.3)$ & $2.7(0.2)$ & $2.7(0.2)$ & 0.70 \\
Drip loss $24 \mathrm{~h}(\%)$ & $2.6^{\mathrm{a}}(0.5)$ & $3.3^{\mathrm{ab}}(0.4)$ & $3.9^{\mathrm{b}}(0.5)$ & 0.05 \\
Drip loss $48 \mathrm{~h}(\%)$ & $4.6^{\mathrm{a}}(0.7)$ & $5.6^{\mathrm{ab}}(0.6)$ & $6.2^{\mathrm{b}}(0.6)$ & 0.04 \\
\hline
\end{tabular}

a,b Least squares means within a row and followed by a different letter are significantly $(P<0.05)$ different.

$\dagger$ Intramuscular fat content.

\$ Longissimus dorsi muscle color evaluated according to 6-point Japanese color scale.

significantly lower $L^{*}$ value for I/I and I/V pigs compared to V/V pigs, while Otto et al. (2007) observed significantly lower $L^{*}$ values for I/I pigs, but no differences between I/V and V/V pigs. Lindahl et al. (2004b) reported a lower $L^{*}$ value (not significant) and lower $a^{*}$ and $b^{*}$ values (significant) in the presence of the I allele (for the pooled I/I/ I/V group). Water-holding capacity, assessed as the measurement of drip loss ( $24 \mathrm{~h}$ and $48 \mathrm{~h}$ ), was significantly affected by the I199V PRKAG3 polymorphism. The lowest drip loss was observed for I/I pigs, but the difference was significant only in contrast to $\mathrm{V} / \mathrm{V}$ pigs $(1.2-1.6 \%, P<0.05)$. The heterozygous $\mathrm{I} / \mathrm{V}$ pigs were situated in between; however, the differences to I/I $(0.7-1.0 \%)$ or V/V $(0.5-0.6 \%)$ tended toward significance $(P<0.15)$. Contrary to our observation of $\mathrm{I} / \mathrm{V}$ position being more or les intermediate, Otto et al. (2007), using four different methods for drip loss evaluation, found significantly lower drip loss values only for I/I genotype; thus, their study positioned genotype I/V closer to V/V genotype. In contrast to the favorable effect of the 199I allele demonstrated in the present study, Lindahl et al. (2004a) observed no significant differences for 24 and $96 \mathrm{~h}$ drip loss between V/V and pooled result for I/V and I/I genotypes. Our study confirms the positive effect of allele I on water-holding capacity. The differences in results regarding the genotypes, in particular the position of heterozygous I/V pigs, can be related to the fact that other studies did not control for the 200Q allele, which is always connected to $199 \mathrm{~V}$ and is known to strongly affect the ultimate $\mathrm{pH}$ and drip loss. 


\section{ACKNOWLEDGEMENT}

This study was financed by the Slovenian research agency through P4-0072 program "Agrobiodiverziteta" and partly by grants of the Ministry of Agriculture, Forestry and Food for national pig breeding program.

\section{REFERENCES}

BRENIG, B. and BREM, G. 1992. Genomic organization and analysis of the $5^{\prime}$ end of the porcine ryanodine receptor gene (ryrl). FEBS 298, 277279.

CHRISTENSEN, L.B. 2003. Drip loss sampling in porcine M. Longissimus dorsi. Meat Sci. 63, 469-477.

CIOBANU, D., BASTIAANSEN, J., MALEK, M., HELM, J., WOOLLARD, J., PLASTOW, G.S. and ROTHSCHILD, M. 2001. Evidence for new alleles in the protein kinase adenosine monophosphate activated $\gamma_{3}$ subunit gene associated with low glycogen content in pig skeletal muscle and improved meat quality. Genetics. 159, 1151-1162.

DE SMET, S.M., PAUVELS, H., DE BIE, S., DEMEYER, D.I., CALLEWIER, J. and EECKHOUT, W. 1996. Effect of halothane genotype, breed, feed withdrawal and lairage on pork quality of Belgian slaughter pigs. J. Anim. Sci. 74, 1854-1863.

ENFÄLT, A.-C., VON SETH, G., JOSELL, A., LINDAHL, G., HEDEBROVELANDER, I., BRAUNSCHWEIG, M., ANDERSSON, L. and LUNDSTRÖM, K. 2006. Effects of a second mutant allele (V199I) at PRKAG3 (RN) locus on carcass composition in pigs. Livest. Sci. 99, 131-139.

FISHER, P., MELLETT, F.D. and HOFFMAN, L.C. 2000. Halotane genotype and pork quality. 1. Carcass and meat quality characteristics of three halothane genotypes. Meat Sci. 54, 97-105.

GUEBLEZ, R., PABOEUF, F., SELLIER, P., BOUFFAUD, M., BOULARD, J., BRAULT, D., LE TIRAN, M.-H. and PETIT, G. 1995. Effet du genotype halothane sur les performances d'engraissement, de de carcase et de qualite de la viande du porc charcutier. J. Rech. Porcine en France. $27,155-164$.

HAMILTON, D.N., ELLIS, M., MILLER, K.D., MCKEITH, F.K. and PARRETT, D.F. 2000. The effect of halothane and rendement napole genes on carcass and meat quality characteristics of pigs. J. Anim. Sci. 78, 2862-2867.

HUANG, L.-S., MA, J.-W., REN, J., DING, N.-S., GUO, Y.-M., AI, H.-S., LI, L., ZHOU, L.-H. and CHEN, C.-Y. 2004. Genetic variation of the porcine 
PRKAG3 gene in Chinese indigenous pig breed. Genet. Sel. Evol. 36, 481-486.

JOSELL, Å., ENFÄLT, A.-C., VON SETH, G., LINDAHL, G., HEDEBROVELANDER, I., ANDERSSON, L. and LUNDSTRÖM, K. 2003. The influence of RN genotype, including the new V199I allele, on the eating quality of pork loin. Meat Sci. 65, 1341-1351.

LARZUL, C., LE ROY, P., GUEBLEZ, R., TALMANT, A., GOUGE, J., SELLIER, P. and MONIN, G. 1997. Effect of halothane (NN, Nn, nn) on growth, carcass and meat quality traits of pigs slaughtered at $95 \mathrm{~kg}$ or $125 \mathrm{~kg}$ live weight. J. Anim. Breed. Genet. 114, 309-320.

LEACH, L.M., ELLIS, M., SUTTON, D.S., MCKEITH, F.K. and WILSON, E.R. 1996. The growth performance, carcass characteristics, and meat quality of halothane carrier and negative pigs. J. Anim. Sci. 74, 934-943.

LE ROY, P., NAVEAU, J., ELSEN, J.M. and SELLIER, P. 1990. Evidence of a new major gene influencing meat quality in pigs. Genet. Res. Cambridge 55, 33-40.

LE ROY, P., ELSEN, J.M., CARITEZ, J.C., TALMANT, A., JUIN, H., SELLIER, P. and MONIN, G. 2000. Comparison between the three porcine $\mathrm{RN}$ genotypes for growth, carcass composition and meat quality traits. Genet. Sel. Evolut. 32, 165-186.

LINDAHL, G., ENFÄLT, A.-C., VON SETH, G., JOSELL, Å., HEDEBROVELANDER, I., ANDERSEN, H.J., BRAUNSCHWEIG, M., ANDERSSON, L. and LUNDSTRÖM, K. 2004a. A second mutant allele (V199I) at the PRKAG3 (RN) locus - I. Effect on technological meat quality of pork loin. Meat Sci. 66, 609-619.

LINDAHL, G., ENFÄLT, A.-C., VON SETH, G., JOSELL, A., HEDEBROVELANDER, I., ANDERSEN, H.J., BRAUNSCHWEIG, M., ANDERSSON, L. and LUNDSTRÖM, K. 2004b. A second mutant allele (V199I) at the PRKAG3 (RN) locus - I/I. Effect on colour characteristics of pork loin. Meat Sci. 66, 621-627.

MILAN, D., JEON, J.-T., LOOFT, C., ANARGER, V., ROBIC, A., THELANDER, M., ROGEL-GAILLARD, C., PAUL, S., IANNUCELLI, N., RASK, L. ET AL. 2000. A mutation in PRKAG3 associated with excess glycogen content in pig skeletal muscle. Science 288, 1248-1251.

MONIN, G., LARZUL, C., LE ROY, P., CULIOLI, J., MOUROT, J., ROUSSET-AKRIM, S., TALMANT, A., TOURAILLE, C. and SELLIER, P. 1999. Effects of halothane genotype and slaughter weight on texture of pork. J. Anim. Sci. 77, 408-415.

NAKAI, H., SAITO, F., IKEDA, T., ANDO, S. and KOMATSU, A. 1975. Standard models of pork colour. Bull. Natl. Inst. Anim. Ind. 29, 69-74.

OTTO, G., ROEHE, R., LOOFT, H., THOELKING, L., KNAP, P.W., ROTHSCHILD, M.F., PLASTOW, G.S. and KALM, E. 2007. Associations of 
DNA markers with meat quality traits in pigs with emphasis on drip loss. Meat Sci. 75, 185-195.

POMMIER, S.A., HOUDE, A., ROUSSEAU, F. and SAVOIE, Y. 1992. The effect of malignant hyperthermia genotype as determined by restriction endonuclease assay on carcass characteristics of commercial crossbred pigs. Can. J. Anim. Sci. 72, 973-976.

PREVOLNIK, M., ČANDEK-POTOKAR, M., ŠKORJANC, D., VELIKONJA-BOLTA, Š., ŠKRLEP, M., ŽNIDARSIČ, T. and BABNIK, D. 2005. Predicting intramuscular fat content in pork and beef by near infrared spectroscopy. J. Near Infrared Spec. 13, 77-85.

SELLIER, P. and MONIN, G. 1994. Genetics of pig meat quality, a review. J. Muscle Foods 5, 187-219.

STALDER, K.J., ROTHSCHILD, M.F. and LONERGAN, S.M. 2005. Associations between two gene markers and indicator traits affecting fresh and dry-cured ham processing quality. Meat Sci. 69, 451-457. 